\title{
Sobre la tragedia griega
}

\section{On Greek Tragedy}

\author{
Mauricio Vélez Upegui ${ }^{1}$ \\ Universidad EAFIT, Medellín (Colombia)
}

Recibido: 27-05-14

Aprobado: 23-07-14

\section{Resumen}

Luego de caracterizar la tragedia griega clásica como expresión de un arte ciudadano que participa por igual de un carácter festivo, cierto régimen discursivo y una clara inscripción físico-espacial, el texto se demora en considerar tres aspectos fundamentales de esta forma dramática inventada por los griegos, a saber: una exposición sobre las fuentes orales míticas de las que los autores echan mano para componer la historia de cada una de las piezas que son llevadas a escena al amparo de un espíritu agonal; una explicación del funcionamiento formal de la tragedia, basado en la alternancia de partes cantadas (coro) y partes recitadas (héroe); y, finalmente, una acotación sobre el sentido -interno y externo- que la acción dramática posee, en tanto elemento articulador de la trama.

Palabras-clave: tragedia ática, Grandes Dionisias, leyenda mítica, canto, recitado y acción dramática.

\begin{abstract}
After characterizing the classic Greek tragedy as an expression of a citizen art, which participates equally from one festive character, a certain discursive regime and a clear physical and spatial inscription, the text is delayed on

\footnotetext{
${ }^{1}$ (mavelez@eafit.edu.co). Magíster en Literatura Colombiana, Universidad de Antioquia, MedellínColombia. Profesor asistente Departamento de Humanidades, Universidad Eafit, Medellín-Colombia. Este trabajo es resultado parcial de la Investigación titulada "Sobre la tragedia griega (Planos de expresión $y$ contenido)", iniciada en el mes de julio del año 2012. Grupo: Estudios en filosofia, hermenéutica y narrativas, categoría A1 en Colciencias, adscrito al Departamento de Humanidades, Universidad Eafit. Otras publicaciones: "Tragedia y reaprehensión mítica" En: Co-herencia. Revista de Humanidades. Medellín: Universidad Eafit, Vol. 10, $\mathrm{N}^{\circ}$ 19; Los desdoblamientos de la palabra. Variaciones en torno al diálogo, Medellín, Editorial EAFIT, 2005.
} 
considering three fundamental aspects of this dramatic form invented by the Greeks; a knowledge: an exhibition about mythical oral sources in which the authors are part of composing the history of each of the pieces that are taken into the scene under an agonal spirit; an explanation of the formal functioning of the tragedy, based on the alternation of the sung parts (chorus) and the recited parts (hero); and finally, a stage direction of the sense -internal and external- which the dramatic action possess, as an articulation element of the plot.

Key-words: Attic tragedy, Great Dionysia, mythical legend, chant, recited and dramatic action.

\section{Introducción}

Arte ateniense por antonomasia, la tragedia germina en el siglo VI a. $\mathrm{C}^{2}$, alcanza su máximo esplendor en el V, llamado convencionalmente el siglo de Pericles, y decae poco antes de iniciarse el IV. En efecto, si el nombre de Tespis tiende a ser asociado con el comienzo de la tragedia, pues no en vano la tradición lo presenta como una suerte de poeta lírico que organizaba encuentros festivos de naturaleza coral, cuyos contenidos hacían alusión posiblemente a episodios relacionados con el doble nacimiento de Dioniso o con el cortejo de sus enloquecidas seguidoras ${ }^{3}$; y si después de Sófocles y Eurípides, muertos ambos hacia el 406/405, la obra de Menandro se identifica con la Comedia Nueva, esto es, con una forma teatral en la que los caracteres de los personajes prevalecen a expensas de la acción, entonces lo que se muestra entre estos dos límites temporales no es otra cosa que un "momento histórico" concreto: el momento comprendido entre la representación de La toma de Mileto, de Frínico, llevada a las tablas, en 492, doce años antes de que los griegos vencieran a los persas en Salamina, y la escenificación, en 401, de Edipo en Colono de Sófocles, tres años después de que Atenas se rindiera ante el poder militar espartano.

La tragedia, sin embargo, no es únicamente una invención ateniense; es, con mucho, una creación ciudadana. Su ciclo vital aparece ligado sustancialmente a la pólis. Como transformación de las antiguas ciudadelas reales que despuntan en Creta y Micenas (por hacer mención sólo de algunos de los núcleos humanos más regios e imponentes), la ciudad constituye un ámbito geográfico y jurídico inédito donde las relaciones entre los hombres adquieren otra dinámica, otra

\footnotetext{
2 Toda fecha que en adelante aparezca en el texto debe sobreentenderse como referida a la indicación "antes de Cristo".

3 "Si prescindimos de la tradición artificial, que opera con figuras nebulosas, como la de Epígenes de Sición (Suda, s.v. Thespis)...el trágico más antiguo es para nosotros Tespis, el ático de Icaria" (Lesky, 2001:110).
} 
disposición, otro ordenamiento, no conocidos hasta entonces. Atrás queda la cerrazón de la estructura económica palatina y la concentración de poder, omnipresente, del soberano. A la distancia, igualmente, descansa el carácter vertical del contacto que media entre el gobernante y el grupo de súbditos bajo su mando. A la zaga, por último, permanece la asimetría de los estamentos que componen el cuerpo social, diferenciado en su momento por un vocabulario que, sirviéndose de una especie de línea de corte imaginaria, no deja de enfatizar el contraste semántico de sus términos: "encima de esta línea están los aristoi (la mejor gente), los nobles hereditarios que poseen la mayor parte de la riqueza y todo el poder. Debajo de esa línea están todos los demás, para los cuales no hay más palabra que una designación colectiva: multitud" (Finley, 2014: 68).

Una vez colapsa esta forma de asentamiento, y tras un largo período denominado "Edad Oscura" (que acaso coincida con el paso de la Edad de Bronce a la Edad de Hierro), el surgimiento de la pólis puede datarse entre los siglos VIII y VII. Con su advenimiento, las cosas cambian de una manera perentoria. Ahora la ciudad instituye, como centro sagrado e inviolable, no la residencia del soberano, siempre sustraída a la mirada indiscreta del demos, del pueblo, sino el ágora, esto es, una zona desocupada, ácrata, isomorfa, visible desde cualquier ángulo, ceñida en su amplia extensión y primordialmente "acotada para el ejercicio de funciones públicas" (Ortega y Gasset, 1993: 136) ${ }^{4}$. Además, al ubicarse el poder en un lugar central, a igual distancia de todos cuantos componen la ciudad, pero ya no en cabeza de un solo hombre, la investidura del gobernante pierde su venerable fascinación y misterio. La consecuencia no es otra que una modificación de las relaciones entre los individuos: el antiguo señorío jerárquico es suplantado por la deliberación entre varones libres e iguales que, hasta donde les es posible, procuran participar, según Aristóteles, de los honores públicos (Política, III, 1275 b, 12 y 1278a, 9). En fin, quienes forman la ciudad, a pesar de las múltiples diferencias sociales que los separan, se reconocen a sí mismos como semejantes en el plano político, a tal punto que todas las cuestiones de interés general son sometidas a un debate en el que "la opinión de cualquiera, libremente expresada mediante la palabra...es puesta a disposición de todos" (Vernant, 2008: 135). Y cuando estos elementos se consoliden, luego de un lento y conflictivo proceso social, la ciudad será testigo, al tomar conciencia de su propia identidad, de no pocas primicias espirituales ${ }^{5}$. Una de ellas es la tragedia.

${ }^{4}$ El ágora (ligado al verbo agoreúo, esto es, hablar en público), en tanto "apertura (cháos) que ordena desde y en torno de sí la masa urbana", es, aparte de un lugar físico, un "lugar ontológico, un ámbito donde el logos crea mundo. El espacio deshabitado de la ciudad, el espacio sin ciudad de la ciudad que constituye el centro de la misma, está vacio justamente porque es el lugar donde, por medio de la palabra, el ser se construye, se hace" (Ezquerra Gómez, 2009: 35).

5 Sea que se interprete como una mistificación, sea que se asuma como una autocontemplación fidedigna de sus propia realidad, lo cierto es que Tucídides tiene conciencia de estas primicias, al afirmar que, en tanto atenienses, han "procurado a su espíritu muchísimos esparcimientos", representados en juegos y fiestas celebradas durante todo el año (Historia, II, 38). 
En calidad de pólis tributaria de los cambios señalados, Atenas, entonces, constituye el marco cívico dentro del cual surge el drama (o la tragedia, para ser más precisos). Sin terciar en el espinoso debate que se ocupa de examinar el origen de dicho fenómeno, indiquemos que la tragedia se consolida como género artístico una vez se dan una serie de condiciones. Tres, quizás, merecen ser expuestas, así sea brevemente: una de carácter cívico-religioso; otra de índole poético-discursiva; y la tercera de naturaleza físico-espacial. Sobra decir que las tres mantienen entre sí relaciones solidarias.

La primera guarda relación con el hecho de que Atenas incorpora al panteón la figura de Dioniso, y procede a fijar en el calendario oficial el mes en que la comunidad instaura y patrocina, mediante liturgia u obligación pública, la fiesta de la divinidad ${ }^{6}$. No conviene olvidar que entre los ciudadanos la vida pública, animada por una ola creciente de autonomía y libertad (obtenida después de que la amenaza persa ha sido puesta a raya), se experimenta de un modo festivo, jovial. Dicho en breve, los días y meses del año se colman de celebraciones religiosas. Más de cien conmemoraciones, cargadas de piedad colectiva, se distribuyen a lo largo del ciclo anual. Ellas incluyen plegarias, ofrendas, sacrificios de animales domésticos, cánticos, peregrinaciones, etc. Se configura así un ambiente agitado y tenso de fervor manifiesto. Sin llegar al extremo de la superstición, cuyo retrato mordaz encontramos en los Caracteres de Teofrasto (1985: 24), la vida religiosa ateniense se fundamenta en una "relación de familiaridad con los dioses" (Vegetti, 1995: 291). Semejante sensación de contacto entre el cielo y la tierra se traduce en un sentimiento especial al cual los griegos dan el nombre de eusébeia, vale decir, el cuidado que los hombres tienen para con los dioses (Platón, Eutifrón, 12e). De conformidad con este sentimiento, la ciudad dispone lo necesario para que el culto a Dioniso tenga lugar. Una de esas disposiciones es la elección de la segunda década del mes primaveral de marzo con el fin de institucionalizar las Dionisias Urbanas o Grandes Dionisias ${ }^{7}$. Se las denomina así para diferenciarlas de otras fiestas dedicadas igualmente a este dios: las Leneas, realizadas en el mes de enero; las del Lagar, en el mes de febrero; y las de la Floración (o Antesterias), muy al

\footnotetext{
${ }^{6}$ Las primitivas fiestas rurales en honor de Dioniso "eran eminentemente rurales y, como exaltaban la fertilidad de la naturaleza, no tenían ningún freno racional... Mas llegó un momento en que estas fiestas constituyeron un problema en vista de los desórdenes que desencadenaban; por ello el Estado ateniense resolvió institucionalizarlas, o sea, que no se prohibieron los excesos sino que se asistió a ellos. Se efectúan entonces por primera vez las fiestas dionisíacas en la propia ciudad de Atenas y en el sitio que para ellas se edifica: el teatro de Dionysos ( sic), templo vivo del dios, en la falda meridional de la Acrópolis" (Posada González, 1986: 16-17).

${ }^{7}$ La tradición atribuye a Pisístrato la fundación, en 536/535, de estas festividades. Al parecer, en lugar de estimular entre los habitantes del Ática un culto "panjónico" ya conocido, el tirano trae a Atenas el "culto de Dioniso venerado en Eléuteras, la aldea (demos) situada en la frontera beocia" (Zimmermann, 2012: 22). Su intención, no exenta de un matiz político, es organizar una celebración que tenga como motivo principal, "no un aristocrático dios olímpico", sino uno que pertenezca a todos, y en especial al pueblo (Lesky, 2001: 100).
} 
comienzo del mes de marzo. Lo que en todas se exalta es tanto el reconocimiento cultual de una fuerza divina que incide en el devenir del cuerpo cívico, cuanto el valor ideológico de la competición como elemento diferenciador de la identidad ateniense.

Las fiestas dionisíacas se plasman al hilo de un género discursivo, el drama, cuyo soporte estético es la mímesis o imitación (segunda condición). La palabra drama, explica Aristóteles, hunde sus raíces semánticas en el verbo drao, que puede ser entendido como "obrar", "actuar" (Poética, 1448a, 25-30). Por eso en el drama se ha de "imitar a personas que actúan". Para el Estagirita, la significación de mímesis o imitación entraña la idea de reproducción. Quien imita algo, y particularmente el actor que encarna un personaje, tiene la tarea de volver a producir, de hacer visible, de patentizar, en un plano artificial, aquello que es posible observar naturalmente. Así lo interpreta García Bacca cuando señala que mímesis, en Aristóteles, connota "conjuntamente reproducción imitativa: una síntesis de acciones artificiales y artísticas" (Introducción, 2000: 39).

Esta concepción de la mímesis discrepa de la de su maestro Platón. Para éste, siempre apremiado por el deseo de conjurar la falsa apariencia, el engaño, la mentira, máxime cuando se trata de reflexionar acerca de la creación poética, imitar es estar versado en lo que parece ser, pero no en lo que en realidad es (República, X, 601c). El imitador (el poeta), al desconocer la naturaleza de las cosas que imita, y al no poder hacer o fabricar las cosas que imita, se contenta con fingir que es un entendido en aquello que constituye el objeto de su acto. Tal fingimiento lo condena a estar alejado de la captación de la verdad. Y más: es esa distancia la que determina el modo de la dicción que ha de emplear, a saber, el modo indirecto del discurso. Indirecto es el modo usado por el poeta cuando "presenta un discurso como si fuera otro el que hablara" (ibid., III, 393c). Diríase que en este caso él elige una perspectiva subjetiva y actúa como si su dicción, su discurso, se asemejara lo más posible a la dicción, al discurso, de cada personaje que, "según anticipa, ha de hablar". Querer asemejarse a otro, en palabra o aspecto, equivale a imitarlo. La imitación consiste en que el poeta pone un discurso en boca de otro, haciéndole creer a quien lo escucha que es éste quien lo emite. Si el incumplimiento de la "ley de verdad" está en la base de la crítica platónica al quehacer mimético, la observancia de la "ley de verosimilitud" está en el núcleo de la defensa aristotélica a dicho quehacer.

Ahora bien, la fiesta dionisíaca que encuentra en uno de los modos de la dicción poética su más pulcra coronación es llevada finalmente a un espacio de encuentro, el teatro (tercera condición). Emparentado con los vocablos thea (mirar) y théasthai (demorarse en la mirada), el término griego theátron -teatro- significa el lugar desde donde se ve o contempla algo. Por eso el teatro denota el espacio de reunión donde los individuos adoptan la condición de mirones, de espectadores (théanos). Sencillos, fabricados en madera, "móviles 
y no estables" (Guzmán Guerra, 2005: 60), los primeros teatros se erigen, para necesidades estrictamente locales, en los siglos VI y V. Dada la constitutiva fragilidad de esta clase de edificaciones, la piedra y el mármol reemplazan después a la madera ${ }^{8}$.

Sin mencionar un sinfín de detalles técnicos que habrían de cambiar a lo largo del tiempo, su diseño responde a tres partes estructurales: el koilón o auditorio, la orquestra o lugar para bailar y la skené o escenario. Como espacio cívico, el auditorio participa del tiempo presente, de las urgencias del aquí y ahora, dado que su aforo lo conforman hombres ${ }^{9}$, si no coetáneos, contemporáneos de los tragediógrafos; como espacio dramático, el escenario, por su parte, tiene relación con el tiempo pasado, ya que los personajes que aparecen en escena proceden del universo del mito o de la leyenda heroica; y como espacio intermediario entre el primero y el segundo, la orquestra, en calidad de elemento destinado a la ubicación de los coreutas (o miembros del coro), mantiene relaciones recíprocas con uno y otro tiempo, debido a que, de un lado, se compone siempre de ciudadanos varones y libres elegidos por sorteo, y, de otro, cumple la función de entonar las partes líricas de las obras.

Diseñadas para que individuos semejantes (desde un punto de vista político) ejecuten funciones diferentes (desde un punto de vista artístico), las tres partes, además de promover la contemplación, ponen el énfasis en la actividad de la audición. De ahí que al teatro no se vaya únicamente a mirar, sino también, y muy especialmente, a oír, a escuchar.

Festejo religioso, acto verbal mimético y edificio teatral, en consecuencia, se fecundan entre sí para hacer posible el acontecimiento de la tragedia. Esta tríada, como decíamos, se enmarca en una ciudad que, no sin resistencias ni sin apuros sociales, logra implantar un régimen de gobierno democrático en cuyo seno lo religioso y lo civil se condicionan mutuamente. Sin la invención de la democracia difícilmente la tragedia hubiera existido, y sin el desarrollo de la tragedia muy seguramente la democracia hubiera padecido con más frenesí el acoso de los viejos poderes depuestos.

${ }^{8}$ El teatro de Dioniso en Atenas, el primero levantado con estos materiales, y descubierto en 1862 , pronto se convierte en el modelo arquitectónico de los demás. Aprovechando la inclinación natural de la ladera sur de la Acrópolis, su construcción se inicia en la Olimpíada 70 y concluye "entre los años 340-330, con Licurgo" (Ghul y Koner, 2002: 172).

9 Por lo que concierne al siglo $\mathrm{V}$, ¿tenían libre acceso las mujeres al teatro, y, en particular, a la contemplación de tragedias? Al respecto, uno de los trabajos más ilustrativos, por la prudencia de las reflexiones y el juicioso análisis de la documentación secundaria, pertenece a Brioso Sánchez. Entre sus múltiples considerandos, destacamos éste en particular: "Tenemos testimonios de que muchachos o niños e incluso esclavos y desde luego forasteros, avecindados o no, podían asistir como espectadores, y en principio, nos es difícil imaginar que no pudieran hacerlo también las mujeres" (2005: 82). Sólo que, como el mismo autor lo señala, aún carecemos de fuentes confiables, extrateatrales o no, que nos muevan a dar una respuesta positiva al respecto. Ni siquiera las alusiones e interpelaciones al público que aparecen en las comedias de Aristófanes deben ser tomadas como noticias ciertas que induzcan a pensar en la posibilidad de la concurrencia femenina al certamen dionisíaco. Muy distinta será la situación en el siglo IV. Como consecuencia de cambios sociales y gustos epocales, la mujer empieza a contar como parte del público asistente (Iriarte, 1996: 23).

Araucaria. Revista Iberoamericana de Filosofia, Política y Humanidades, año 17, n 33. Primer semestre de 2015. Pp. 31-58. ISSN 1575-6823 e-ISSN 2340-2199 doi: 10.12795/araucaria.2015.i33.02 
Así las cosas, queremos dedicar este escrito tan sólo a considerar lo que, a nuestro juicio, dota de un profundo valor artístico a la tragedia, en cuanto especie del género dramático auspiciada por la ciudad. El contenido de este valor puede formularse como sigue: si, entre los griegos, el arte, entendido como una actividad que provee un cierto tipo de conocimiento basado en la experiencia, no constituye un ámbito separado de las preocupaciones de la ciudad; y si la ciudad, al erigirse históricamente de espaldas a la realidad de los viejos emplazamientos de soberanía, no cesa de auto-concebirse teniendo a la mano el espejo de su propio pasado, entonces una parte sustancial del arte trágico se define por su función de escenificar (de dramatizar) el contenido de la acción mítica, con el fin de ofrecer a los ciudadanos algunos elementos de juicio que les ayuden a comprender lo que significa ser parte de una misma comunidad y lo que supone, en términos de exigencia ciudadana, reconocerse en ella, y de brindar al pueblo, además, una imagen amplificada del hombre "que sirve de símbolo de su propio destino y le da, en últimas, significado" (de Romilly, 1997: 167).

Leída en sus implicaciones, la idea mencionada supone, entre otros, tres componentes: a) las fuentes (o apoyos "literarios"), b) el modo imitativo del discurso trágico (o agón entre coro y actor) y c) el eje de la trama ${ }^{10}$ (o significado de la acción trágica).

\section{a) Escarbando en el pasado: las fuentes "literarias"}

Con la única excepción de Los persas, pieza -de entre las conservadas- con la que Esquilo, en 472, se atreve a representar un acontecimiento histórico, la tragedia hunde sus raíces en el mito, y, más todavía, en la mitología griega, en el sentido de "conjunto de relatos que conciernen a los dioses y a los héroes, es decir, a los dos tipos de personajes a los que las ciudades antiguas les dedicaban un culto" (Vernant, 2002: 100). Si el mito habla de los primeros tiempos en los que aún no existe conciencia histórica, y si la historia habla, según la conocida distinción aristotélica, de lo particular ("lo que ha sucedido -qué hizo o qué le sucedió a Alcibíades-"), entonces los autores trágicos hablan de lo general ("a qué tipo de hombres les ocurre decir o hacer tales o cuales cosas verosímil o necesariamente" -Poética, 1451b 5-1-)(Vélez Upegui, 2013: 78). De ahí que se sumerjan en el pasado, en la tradición oral que es memorizada y conservada ritualmente por la colectividad, y extraigan desde ese fondo común,

\footnotetext{
${ }^{10}$ Escribimos "trama", a sabiendas de que el vocablo empleado por Aristóteles es mythos. Sin duda ésta es una de esas palabras que muestran una historia transida de variaciones semánticas. Su uso más remoto se encuentra en Homero, quien la emplea preferentemente para designar una notificación, una proclama o, si se quiere, una palabra que "organiza, decreta, ordena, instituye, crea" (Echavarría Yepes, 2012: 86). Pero en Aristóteles la palabra admite ser entendida, a juzgar por el pasaje que señala que el fin de la tragedia es la "composición de los hechos" (Poética, 1450a 33), como "intriga o ensamblaje de acciones cumplidas" (Ricoeur, 1992: 222).
} 
desde ese depósito de materiales orales, los motivos y temas con los cuales componen imitativamente sus obras. Antes que simples charlatanerías con las que se pueden embaucar los oídos de hombres y mujeres ingenuos y cándidos, y más que complejos y elaborados relatos donde se dan cita, transfigurados en apariencias antropomórficas y zoomórficas, las potencias y fuerzas del cosmos, los mitos comportan, conforme a la misma evolución semántica del término, una dimensión de lo ficticio que es aprovechada por los autores trágicos para inventar una nueva creación artística. Provistos, pues, de un extenso y heterogéneo conjunto de narraciones donde se cuentan las luchas, los amores, las gestas, las pasiones y los odios entre inmortales y semidioses, Esquilo, Sófocles y Eurípides (junto a otros poetas de los cuales apenas si se conocen sus nombres) acometen la labor de dramatizar el mito.

¿En qué consiste esta labor? En un ejercicio de libertad expresiva, sustentada en una nueva racionalidad crítica y materializada en forma de representación teatral. Nada de relevante, de notable, de ejemplar incluso, tendría el esfuerzo dramático de los autores trágicos, si su energía poética se hubiera ceñido simplemente a frecuentar su propia y particular tradición, respaldada como afirmamos en un acervo cultural amplio, y a prolongarla por otros medios, quizás para ensancharla, quizás para tornarla más rica y diversa, quizás para reproducirla, en calidad de epígonos o piadosos herederos. Un lazo de continuidad habría anudado el pasado y el presente, y cualquier asomo de conflicto, de extrañamiento, de fractura entre ambos períodos pasaría en silencio, aletargado por la bruma de los años. De haber bastado el hecho de que los poetas se remontaran hasta el origen de las genealogías de unas cuantas familias para encontrar la semilla de sus propias creaciones (tal y como lo indicara Aristóteles ${ }^{11}$ ), cualquiera habría podido dudar del valor estético de las mismas, empujado por las determinaciones de una exigencia estética moderna. Pero como Nietzsche lo advirtiera en su momento, muy al inicio de la meditación que luego lo conduciría a la redacción de su texto sobre el origen del "drama musical griego", la originalidad de los poetas trágicos habría que buscarla, si de tal cosa se tratara, no allí donde algunos creerían que debería encontrarse (a saber, en la novedad, en la exclusividad, en el interés que haría mutis por el pasado o que abjuraría de los vínculos con la tradición), sino donde nunca imaginaron que podría estar, es decir, en el acontecimiento de su retorno (2004: 88).

Cuando los autores trágicos, adoptando una actitud anacrónica, vuelven su mirada al pasado, desde el presente cívico en el que les es inevitable vivir, no lo hacen para tirar maquinalmente del hilo de la tradición, sino para tejer

11 "Al principio, en efecto, los poetas versificaban cualquier fábula; pero ahora las mejores tragedias se componen en torno a pocas familias, por ejemplo, en torno a Alcmeón, Edipo, Orestes, Meleagro, Tiestes, Télefo y los demás a quienes aconteció sufrir o hacer cosas terribles" (Poética, 1453a 17-21). 
nuevos lienzos. En esa medida, se sirven a discreción, voluntariamente, de una serie de filtros racionales con los cuales tratan de tamizar el contenido de los relatos fundacionales. Éstos, ¡qué duda cabe!, continúan existiendo, pero ahora la nueva actitud exhibida ante ellos no responde a una adhesión sagrada e intocable. En manos de estos autores trágicos, el mito es tratado con libertad y sin miramientos de descendiente. Las viejas y venerables historias, aunque conservan su núcleo básico, son retocadas y contadas de otra manera (de Romilly, 1997: 171).

Esa otra manera de retocar el mito, para extraer de él, no los motivos descriptivos que sazonan la historia, sino los motivos asociados que dan cuerpo a la acción, depende no sólo de la propia naturaleza del mito (un relato que por definición es irreducible a una sola versión, a la unidad de una sola composición), sino del tipo de racionalidad que lidia por instalarse en la ciudad, como prenda de garantía de una nueva captación de lo real. No debe olvidarse que de ser una ciudad que en el siglo VI es "en numerosos aspectos muy semejante a cualquier ciudad-Estado griega e incluso en situación de inferioridad respecto a algunas de ellas por la escala de sus empresas, hasta tal punto que su literatura no resistiría la comparación con la de las ciudades griegas jónicas o con los primitivos cantos espartanos; no poseía científicos o filósofos dignos de mención" (Bowra, 2003: 18), Atenas pasa a ser, en menos de un siglo, un centro urbano de referencia casi pan-helénica. Gracias a las reformas sociales, económicas y políticas de Solón, primero; al impulso dado por Pisístrato a diversos cultos comunitarios como el de Atenea y particularmente a las artes (al instituir, respectivamente, las Grandes Panateneas y las Dionisias Urbanas o Grandes Dionisias), segundo; y al nuevo ordenamiento territorial instaurado por la democracia de Clístenes, y el cual supone, desde el 508, la creación de diez tribus artificiales, cada una de ellas formada, con arreglo a tercios poblacionales, por habitantes procedentes de la ciudad propiamente dicha, el litoral y la llanura interior, tercero (Gil Fernández, 2009: 36; Sinclair, 1999: 19-20), la ciudad adopta, por vez primera en su historia, una forma de gobierno democrática.

La democracia convierte el lógos (la unidad de pensamiento y palabra) en el genuino protagonista de la vida cultural ateniense. Presente en los tribunales, a donde se asiste para escuchar los pros y contras de un alegato legal mediado por la necesidad de discernir y elegir lo justo; en la asamblea, a cuyo espacio se acude para escuchar la opinión del orador que aconseja o desaconseja respecto de un asunto que interesa explícitamente a la comunidad cívica; en los edificios deportivos, plazas u otra clase de localizaciones a los cuales se concurre para proclamar al vencedor $\mathrm{u}$ orador cuya excelencia en las justas merece los aplausos; en el ágora, a la que se frecuenta para intercambiar pareceres sobre asuntos menudos de la existencia ordinaria o graves asuntos de incumbencia pública; y en el teatro, en cuyo auditorio se sientan los espectadores que son 
testigos menos de un espectáculo que de una celebración religiosa y social, el lógos, en cada uno de los casos considerados, impacta profundamente la vida individual y colectiva de los atenienses, y determina tajantemente el destino judicial, político, social, intelectual y artístico de la pólis.

Dos elementos son comunes a todas estas manifestaciones lingüísticas: primero, la formalización de cinco géneros discursivos que gravitan en torno a la vida ciudadana y la marcan con un sello democrático inestimable: el judicial, en el caso de los tribunales; el deliberativo, en el caso de las asambleas; el epidíctico, en el caso de los juegos u otro tipo de acontecimientos que desembocan en el encomio o la diatriba; el filosófico, en el caso de los diálogos socráticos o platónicos, escenificados en espacios abiertos o cerrados; y el dramático, en el caso de las representaciones teatrales. Destinado a la elocuencia, un arte oratorio, natural o refinado mediante ejercitación técnica, como el que enseñan los sofistas (esos extranjeros que se nombran a sí mismos "maestros de sabiduría" y en contra de cuyas perniciosas enseñanzas, teñidas del más contradictorio escepticismo, se levanta la figura contestataria de Sócrates, proclamando a quien quiera escucharlo que "la virtud es conocimiento" y no cháchara con apariencia de verdad), se adueña de la ciudad, irrigando con su poder persuasivo o convincente los más diversos lugares del espacio social (Guthrie, 2005: 77).

Segundo: un espíritu agonal, en el doble sentido de la expresión (como duelo verbal y evento respecto del cual alguien se alza con la victoria y alguien sale perdedor), insufla de confrontación, de debate, de pugna civilizatoria, el uso de la palabra proferida. Si no fuera por sus connotaciones estrictamente legales, diríamos que el lógos es el tribunal popular ante el cual son llevados, para ser discutidos, criticados, derogados o implantados, mediante gregarias opiniones o sesudas argumentaciones, todos los aspectos de la existencia comunitaria: las leyes, los delitos de impiedad, los crímenes de sangre, las disensiones de vecindad, las declaratorias de guerra, las actuaciones atléticas, las ideas, y, por supuesto, las narraciones míticas. Esta racionalidad, de índole agonalmente discursiva, es adoptada por los autores trágicos, quienes la actualizan, dentro de la estructura dramática, bajo la forma de una alternancia conflictiva entre las partes cantadas y las partes recitadas.

\section{b) El agón entre coro y héroe}

Sin agón, escribe Rodríguez Adrados, "no se podría comprender lo que es una tragedia griega" (1983: 126). Quienes se enfrentan, quienes disputan, en un duelo de palabra o acción, son dos o más actores, éstos y el coro, o un coro que, según el desarrollo de la acción, puede dividirse en dos mitades enfrentadas (p. e., el final de Los siete contra Tebas). De las tres posibilidades, nos interesa 
la segunda, manifiesta en no menos de quince piezas, de las treinta y dos que han llegado hasta nosotros. ¿Qué sentido tiene cada uno de estos agentes en la economía general de la obra trágica?

Consideremos el coro, en primer lugar.

A diferencia del drama satírico, cuyos coros están integrados básicamente por sátiros, personajes míticos asociados al culto de Dioniso, y a diferencia de la comedia, que puede incluir personajes "históricos" (como el Sócrates de Las nubes) o individuos con rasgos animalescos (Las avispas), los coros trágicos se componen de personajes tomados en su mayor parte de la tradición épica. Los hay de ancianos -Los persas, Edipo rey, Heracles-, cazadores-Hipólito-, marineros - Áyax, Filoctetes-, etc., o de esclavas -Las coéforas-, extranjeras cautivas -Las troyanas-, divinidades -Las Euménides-, así la ejecución del canto esté a cargo únicamente de hombres. Y más: como en Las Suplicantes de Esquilo, el coro puede obrar de actor principal. Disfrazados y enmascarados, los miembros del coro (coreutas), conducidos por uno de sus miembros, el jefe del coro (corifeo), se sitúan en la orquestra, según antes subrayábamos, y desde allí proceden a ocuparse de las partes cantadas de la obra. Los coreutas y el corifeo, aparte de cantar, acompañan ritualmente las acciones de los héroes, las glosan con comentarios de contenido moral, las anticipan visionaria o simultáneamente, y, lo más frecuente, toman partido por las decisiones que socavan el ánimo de los distintos personajes, no sin esforzarse en persuadirlos mediante una gama variada de recursos religiosos y retóricos (oraciones, trenos, comparaciones).

Aunque algunos, más románticos, como Schlegel, han creído ver en el coro una especie de "espectador ideal" de la tragedia, inmerso de lleno en la representación, conocedor de la prehistoria del drama y así mismo agente colectivo capaz de prever su desenlace y conmoverse con el destino de los personajes ${ }^{12}$, y otros, más escépticos y mordaces, como Perrault, han supuesto "que el coro se inventó sólo porque los autores necesitaban un vehículo para los lugares comunes que llevaban en el bolsillo: la inevitabilidad de la muerte, la inconstancia de los negocios humanos, las inconveniencias del trono, la virtud de la inocencia, etc." (Citado por Rosenmeyer, 1983: 147), por nuestra parte creemos que el coro funge, si no de conciencia moral colectiva, de agente catalizador entre la tradición y las nuevas realidades ciudadanas: por medio de su canto y a través de sus diálogos recitados, el coro hace que el pasado lírico de la ciudad (integrado por el magisterio gnómico de poetas como Solón

12 Reproducimos el pasaje completo, dada la importancia que durante el Romanticismo se le concedió a este elemento de la estructura trágica: "Debemos concebirlo [refiriéndose al coro] como pensamiento personificado acerca del asunto reproducido, materializado y con la participación asumida por el poeta en la representación como portavoz de toda la humanidad... El coro es, en una palabra, el espectador idealizado. Mitiga la impresión de una representación profundamente estremecedora o profundamente conmovedora, al oponer al espectador sus propias emociones expresadas líricamente, es decir, musicalmente, trasladándole al lugar de la reflexión” (Citado por Zimmermann, 2012: 123).

Araucaria. Revista Iberoamericana de Filosofía, Política y Humanidades, año 17, n 33. Primer semestre de 2015. Pp. 31-58. ISSN 1575-6823 e-ISSN 2340-2199 doi: 10.12795/araucaria.2015.i33.02 
y Píndaro) se vuelva en cierto modo contemporáneo, de suerte que desde el presente cívico que es remozado por la escritura se pase al cuestionamiento sobre el valor oral de esa misma tradición.

$\mathrm{Si}$ arquitectónicamente los semicírculos de la orquestra se adentran por igual en la escena y en el auditorio, indicando así su doble conexión con el presente y el pasado de la ciudad, funcionalmente los miembros del coro hacen las veces de mediadores entre el mundo de los héroes y el de la mancomunidad de los ciudadanos. La mediación, al enlazar las coordenadas de tiempo y espacio, no pierde de vista el futuro. Lo que en escena acontezca y sea comentado, explicado o ilustrado por el coro, ya en forma de apotegma, ya en forma de himno, concierne, desde el presente de expectación, al destino de la pólis. De no ser porque la hipótesis resulta temeraria, sostendríamos que la orquestra reproduce, analógicamente, el espíritu del ágora. En efecto, al ocupar el círculo de la orquestra, los coreutas son al teatro, lo que, al permanecer en el ágora, los ciudadanos son a la ciudad.

Más allá, pues, de sus funciones rituales o dramáticas (indicar el componente festivo que envuelve las canciones agrarias originales; ensalzar, ponderar, alabar la acción sólo para encubrir sus consecuencias fatales; tranquilizar el ánimo de quienes, dotados de carácter, se ven espoleados por una pasión destructora; "exponer los elementos de estabilidad de las vidas del pueblo, de los atenienses corrientes, para amortiguar el ascenso y la caída del carácter heroico"; vaticinar una justicia venidera, etc.), el coro se planta en la orquestra no sólo para acompañar activa, moderada o pasivamente la acción con sus cantos, sino para remover, como ente colectivo interrogante, las seguridades enquistadas de una tradición que empieza a volverse problemática.

Al unísono, como cuerpo colectivo, o de manera individualizada, como conductor coral, el coro o su jefe puntean, entre los distintos episodios, y aún durante el desarrollo mismo de éstos, bajo la forma de pasajes epirremáticos, el curso dramático de la acción. Su carácter combativo y persecutorio puede contrastar con uno cuyo grado de participación en la acción es menor. Cierto que a veces su "actuación", a la hora de pronunciarse frente a una decisión o acción cumplida, lo muestra indeciso, ambiguo, dubitativo; pero también es cierto que tarde o temprano termina pronunciándose a favor o en contra de los hechos acaecidos. Al final de la evolución del género el papel del coro habrá disminuido considerablemente hasta el punto de convertirse en un simple añadido con una función técnica subsidiaria.

¿Qué decir del héroe, el otro elemento de la estructura dramática que, en alternancia con el coro, domina con sus diálogos (a veces, con su esgrima dialéctica) la escena trágica?

En la captación poética de los griegos, los héroes son seres pertenecientes a los tiempos remotos, nacidos, según el Mito de las edades de Hesíodo, a 
continuación de la raza de los hombres de bronce. La "estirpe divina de los héroes" (v.160), llamados semidioses no sólo por haber nacido de la unión entre una divinidad (dios o diosa) y un ser humano, sino también por su condición mortal o efímera, se tiene en la antigüedad por "justa y virtuosa", de un lado, y por soberbia y brutal, de otro. El carácter heroico se balancea así entre dos extremos: el sobrehumano, caracterizado en su singularidad por el empeño puesto para ir más allá de los propios límites, y por ello mismo no exento de incurrir en toda clase de excesos, y el infrahumano, vecino de una humanidad no civilizada. Sin renunciar a imaginar el segundo, los griegos enaltecen el primero al considerarlo como la manifestación más excelsa del hombre. Por lo menos esa es la percepción de Aristóteles: "Los héroes eran, tanto física como moralmente, superiores a los hombres" (Política, VIII, 1332b). Ya empeñen su existencia en el combate armado, en el enfrentamiento bélico, sabedores de que les aguarda una muerte temprana (caso de Aquiles), ya afronten toda clase de peligros, incluido el de la guerra, a sabiendas de que pueden salir bien librados si combinan adecuadamente fuerza e ingenio (caso de Heracles o Ulises), los héroes cuentan con un destino póstumo: la fama imperecedera (kleós) y la gracia ( $k y ́ d o s)$ derivadas del canto épico, así como el culto público que es establecido por las ciudades después del siglo VI. Culto en el que resuena, a distancia, la filiación de estos personajes a las antiguas familias aristocráticas que, durante siglos, se alzan en Atenas con parte del poder político y religioso.

"Antiguos hombres que, a causa de lo esforzado de su proceder, tras la muerte adquirieron un rango superior al humano, es decir, el heroico y, en consecuencia, recibían culto" (Bauzá, 2007: 32), los héroes, esas figuras míticolegendarias que encarnan las más diversas pasiones (discordia, venganza, envidia, soberbia, avaricia, lascivia, ira, pero también lealtad, deseo de justicia, fraternidad, amor, respeto, vergüenza), son llevados a las tablas por los autores trágicos portando siempre máscaras. Las máscaras tras las cuales ocultan sus rasgos naturales cumplen una doble función: marcar todavía más la distancia entre su condición legendaria y la condición mortal de los hombres del siglo $\mathrm{V}$ e identificar, vía el modo imitativo, los roles diferenciados que desempeñan. La imitación heroica, aunque agregue una dosis de ficción al mundo configurado teatralmente, introduce un plano de realidad nueva, necesario para actualizar el pasado que se quiere representar. La finalidad derivada del ejercicio que consiste en dramatizar el mito, del cual los dioses y héroes forman parte, es, dicho con una expresión paradójica, la de volver presente lo ausente ante los ojos de los espectadores.

Coro y héroe, así caracterizados sin una pretensión exhaustiva, alternan conflictivamente las tiradas trágicas del canto y el recitado porque su función reside en debatir sobre un asunto en el que ambas partes se implican mutuamente. En la tragedia, en términos generales, todo gira en torno de una suerte de macro- 
secuencia dramática, compuesta de tres partes que son atravesadas de principio a fin por el conflicto, por el agón: el comienzo, correspondiente al prólogo, abre la posibilidad del agón; el medio, correspondiente a aquel o aquellos episodios en los que se produce la peripecia (con o sin reconocimiento, con o sin lance patético), efectúa el agón, bien en forma de diálogo, bien en forma de acción no dialógica; la tercera, correspondiente al desenlace, concluye el agón, ora en forma negativa (final trágico), ora en forma positiva (final trágico-cómico, o, más bien, "feliz", como en el caso de La Orestíada). En cualquiera de los tres estados (posibilidad, acto y resultado), el agón puede combinarse con acciones de naturaleza ritual o cultual que contribuyen a darle a la obra un mayor dramatismo religioso. Variadas causas, a menudo ligadas a una temporalidad anterior, desencadenan la enemistad y se convierten al mismo tiempo en temas trágicos: bandos en guerra (Los persas), trasgresión de una norma civil o religiosa (Antígona), animadversión entre sexos opuestos (Hipólito), el deseo de venganza (Las coéforas, Electra, Medea), la expulsión del gobernante (Edipo rey), la instauración de un culto prohibido (Las bacantes), etc. Siempre motivada por una causa determinada, la querella se actualiza en el agón propiamente dicho, puesto que está en juego no tanto el destino de un individuo, cuanto el de la colectividad (llámese humanidad, ciudad o grupo humano). De ahí que a veces un árbitro (por lo general una divinidad) intente mediar, con resultados exitosos o fallidos, en la disputa misma. La conclusión implica la muerte, el destierro, el rapto, y al extremo, una situación incierta cuya resolución definitiva debe producirse en un agón ulterior (Rodríguez Adrados, 1983: 202-204). La obra concluye con el cierre de la secuencia.

Si los héroes, remontando el tiempo que los separa del presente cívico y achicando el espacio que los aleja de Atenas, son llevados a las tablas con el fin de que sus historias vuelvan a cobrar vida en el escenario ante la mirada expectante del público, no es porque la ciudad, pese al culto que les rinde, añore extemporáneamente su imagen para intentar convertirla en un anacrónico modelo de acción, o porque evoque intempestivamente su actuación paradigmática como molde de una praxis sobresaliente que puede ser extendida al conjunto de la comunidad, sino porque su imagen, su actuación (la de los héroes), arraigada esencialmente en la areté (en la excelencia) individual, en el eximio desempeño personal, muy al contrario, no se acomoda, no se aviene a la observancia de los nuevos valores que los ciudadanos de la pólis instauran para sí, en el marco de una democracia auto-constituida, de una manera completamente autónoma, intencional y voluntaria, es decir, sin que medie, como otrora había acontecido, en el pasado referido por Homero y Hesíodo, "una fuente extra-social, divina, trascendente que diga el derecho, que diga lo que es o no es bueno, lo que es o no es justo" (Castoriadis, 2006: 44). Sobre la base de una ley teatral, la alternancia conflictiva del coro y los héroes da cuenta, en el orden social, de 
la tensión existente entre la forma de gobierno democrática y los antiguos privilegios de sangre de una aristocracia superviviente.

A los ojos de los atenienses, doblemente representados en el teatro por el coro y los espectadores, los héroes (léase, los viejos ideales aristocráticos), nos aclara Vernant, se convierten en un problema para sí mismos y para la ciudad (1972: 306). Si, concretamente en Homero y Píndaro, la figura heroica se destaca entre todas las demás por su arrojo y valentía ardorosa, rayana en el comportamiento insano, por su deseo de querer ser el primero, el mejor, el guerrero ejemplar, el hombre protegido por los dioses que afirma su superioridad derrotando a toda clase de adversarios, en los autores trágicos esa figura, bendecida por el culto público, no hace más que poner en entredicho los ideales bajo los cuales la democracia se debate, no sin resistencia, en contra de las viejas estructuras palatinas que despuntan en la evolución histórica de la pólis: sentido de asociación e igualdad ante la ley, pero no individualismo a ultranza; autocontrol y moderación como los exigidos a los hoplitas por la formación en falange o como los impresos en el frontispicio del templo de Apolo en Delfos ("Conócete a ti mismo" y "Nada en demasía"), pero no actuación aislada inspirada por el valor personal; y acatamiento de las normas grupales, pero no excelencia particular cimentada en el espíritu de rivalidad.

Lo que los héroes personifican es cabalmente lo contrario del nuevo derecho que, en Atenas, se intenta fraguar al precio de un conjunto de leyes cuya elaboración inicial y posterior divulgación pasa por el debate oral y la fijación escrita. Para ese cuerpo de ciudadanos, de hombres políticos, que es teatralmente el coro, la actuación heroica exige ser examinada, interrogada y juzgada puesto que en ella puede hallarse alguna clase de comprensión sobre las motivaciones psicológicas, las significaciones sociales y los efectos legales de quienes, al actuar, dan pie a la creación de las leyes; leyes racionales, "susceptibles de ser aplicadas por igual a todos" (Vernant, 1992: 64), y no fórmulas rituales emitidas por el soberano sin posibilidad alguna de réplica; leyes salpicadas de cierta clase de ambigüedad dado que, en lugar de apoyarse en principios indudables, se forman provisionalmente de "distintos niveles, algunos de los cuales ponen en duda los poderes religiosos, el orden del mundo, Zeus, diké, y en otro extremo plantean los problemas de la responsabilidad humana, tal como los filósofos están discutiendo ya" (Vernant, 1972: 301); leyes, en fin, cuya conservación y acatamiento colectivo reclaman el uso de la escritura como base comunicativa para la creación de una cultura común.

El teatro, sin ser una asamblea donde se votan las leyes, sin ser un tribunal donde se condena a los infractores de éstas, y sin ser el ágora donde la gente del común se reúne para rumiar las implicaciones de las leyes aprobadas, es el espacio institucionalizado por la ciudad para que los autores de tragedias, comedias y dramas satíricos, a través del modo imitativo y bajo la forma 
alternada de canto y recitado, exploren el complejo hecho de la acción (de la actuación) humana.

\section{c) El significado de la acción dramática}

Para los atenienses del siglo $\mathrm{V}$, la representación imitativa de las acciones humanas, nobles o bajas, constituye la quintaesencia del teatro. Como afirmara Aristóteles, poetas trágicos son, no los que escriben en verso o en prosa, sino quienes, apoyándose en el mito, estructuran tramas, en espera de que unos actores imiten delante de numerosos espectadores los actos de los personajes que dan vida (ficticia, por supuesto) a dichas figuraciones. Contra Nietzsche, que pone el acento en la pasión y por ende en el padecimiento del coro y el héroe, olvidando o refutando a la sazón la enseñanza aristotélica, reacciona Vernant y otros, aduciendo, conforme a una explícita rehabilitación del autor de la Poética, que "lo que la tragedia presenta es el hombre enfrentado con su acción, en el quid de la acción, reflexionando sobre su acción y no sintiendo que como hombre pertenece a un mundo aparte" (1972: 307). No sin describir el ámbito en el que se desarrolla la tragedia como un universo que está signado por la adversidad, el dolor y el sufrimiento de los héroes, propiedades todas que están escritas en su fatídico destino, García Gual, en términos similares, señala que en la tragedia "hay, pues, una urgente necesidad de actuar - una anánke de la praxis que constituye el drama- y esa actuación comporta una terrible experiencia" (2006: 186). La inferencia sale sobrando: sin acción, ejecutada o por ejecutarse, la tragedia es inconcebible. Agreguemos algo más: sin una acción funesta que esté antecedida, plasmada o continuada por un agón celebrado entre uno o más actores y/o el corifeo, y cuyo intercambio dialógico es acompañado por una intervención coral que puede expresarse poéticamente de múltiples maneras y con finalidades diversas, no es posible hablar de tragedia como forma dramática.

Veamos cómo se manifiesta esta tesis en tres ejemplos concretos.

En la párodos de Agamenón, por ejemplo, el coro cita las palabras que el rey emite cuando, varada la flota aquea en las playas de Áulide a consecuencia de una afrenta infligida por uno de sus hombres a la diosa Ártemis (cazar un ciervo en un bosque cercano que estaba consagrado a ella), oye decir al augur Calcante que la divinidad sólo aplacará su cólera cuando él sacrifique a una de sus hijas:

\footnotetext{
"Cruel es mi destino si no cumplo, pero también cruel si degüello a mi hija, de mi hogar la alegría, y con un chorro de sangre virginal yo mancho junto al altar estas manos de padre. ¿Cuál de los dos partidos está libre de males? ¿Y cómo puedo abandonar mi escuadra traicionando así mis alianzas?" (vv. 205-210).
}

Y avanzada la obra, en el momento en que ésta se mueve hacia la peripecia, se configura la célebre escena de la alfombra: Clitemnestra, su esposa, experta 
en un amor enhebrado de zalamerías, mentiras e infidelidad, saluda larga y efusivamente al soberano que por fin llega a su tierra tras años de ausencia y luego de un periplo sembrado de obstáculos, y lo invita a que baje del carro posando sus pies, no sobre el áspero suelo, sino sobre un tapiz rojo que sus esclavas han de desplegar a una orden suya. Como si intuyera lo que semejante acción arrastra simbólicamente consigo, Agamenón se resiste, no sin alegar que tal proceder, aparte de ser femenino, podría despertar la envidia de otros, de suerte que con un tono que parece inflexible le responde a su mujer:

"No me atrevo a hacer esta acción que tu acabas de indicarme" (vv. 930-931).

En Áyax, una de las piezas de Sófocles más movidas, por tres veces se repite, como leit motiv, la misma pregunta. Al comienzo, el héroe, que ya ha cometido su acción demente (matar las reses que el ejército aqueo tenía como parte del botín y a todos los pastores que se ocupaban de ellas, creyendo insanamente que eran los mismos hijos de Atreo y aún el astuto Odiseo a quien aquéllos habían entregado, previo certamen, las armas de Aquiles), parece volver sobre sus cabales y, casi al término de un extenso parlamento en el que reconoce la abominación en la que ha caído como consecuencia de su mente enferma, se cuestiona:

"Y ahora, ¿qué he de hacer? Soy declaradamente odiado por los dioses, me aborrece el ejército de los griegos y toda Troya y estas llanuras. ¿Recorreré el Egeo para volver a casa dejando a los Atridas y este fondeadero? ¿Y ahora con qué cara me muestro a Telamón, mi padre? ... ¿Deberé, pues, marchar al baluarte troyano y, en singular combate, realizar proezas para morir después?" (vv. 457-468).

Más adelante, en el punto en que la obra avanza hacia la peripecia, Tecmesa, la concubina-esposa de Áyax, descubre que, en contra de aquello que le había hecho suponer el héroe (buscar un paraje aislado para dar gracias a los dioses por haber recuperado la cordura), Áyax se ha suicidado, atravesado por su "propia" espada (la espada que había recibido de Héctor en muestra de hospitalidad). A sabiendas del destino que le aguarda a ella y a su hijo, como viuda y huérfano respectivamente, prorrumpe en lamentaciones ante el coro y pronuncia estas palabras:

“¡Ay de mí! ¿Qué he de hacer? ¿Quién podrá levantarme? ¿Y Teucro?” (vv. 920-921)

Hacia el final de la tragedia, un mensajero enviado por Teucro llega al campamento griego ansioso por notificar el vaticinio de Calcante, según el cual si Áyax sale de su tienda y nadie lo retiene, como en efecto ocurre, el 
héroe segará su vida con sus propias manos. Llegado Teucro a la escena, esto es, al matorral donde su hermano se ha quitado la vida, contempla el cuerpo ensangrentado y, tras una tirada en la que se lamenta por lo acontecido, interpela a uno de los miembros de su séquito:

“¡Ay de mí! ¿Qué he de hacer? ¿Cómo arrancarte de esa pérfida espada que amarga te quitó tu último aliento?” (vv. 1024-1025).

En Medea, la heroína, a quien precede una sanguinaria estela de muerte (pues al emprender la huida con Jasón, desde su patria situada en los confines del mar Negro -la Colquíde-, ha despedazado a su hermano Aspirto que los perseguía, y llegada como extranjera a Yolco, en la región meridional de Tesalia, logra con ardides que las hijas de Pelias, el usurpador del trono en ausencia de Jasón, se conviertan en las asesinas de su propio padre), exhibe un carácter ambiguo: por su talante hosco, leonino, violento, acrecentado por las desdichas que se ciernen sobre su calidad de bárbara en tierras griegas (tierras en las que su esposo pacta casarse, en segundas nupcias, con Glauce, hija de Creonte, rey de Corintio), se diría que es una mujer resuelta, arrojadiza, temeraria, que no se contiene cuando de maquinar amenazas contra sus enemigos se trata, es decir, "contra el que ha concedido la novia, contra el que la obtiene, y contra la casada" (vv. 288-289), a saber, Creonte, Jasón y Glauce; pero por su condición de mujer que se sabe a sí misma "sola, en ciudad ajena, ultrajada por un hombre, como botín robada en una tierra bárbara, sin madre, ni hermano, ni parientes para cambiar de fondeadero en esta desgracia" (vv. 255-260), su impía y pérfida mente vacila en varias ocasiones sobre cuál debe ser su proceder. Pese a estar domeñada por el dolor, el orgullo y el deseo de venganza, Medea, muy al comienzo de la pieza, duda acerca del procedimiento que usará para "dejar en cadáveres" a sus tres enemigos:

"Tengo muchos métodos de causarles la muerte, pero no sé, amigas de cuál echar mano primero" (vv. 276-278).

Y cuando, en el desarrollo de la obra, tras haber conseguido la muerte de Glauce y de Creonte, está a punto de cometer el asesinato de los hijos nacidos de su propia entraña, exclama ante el coro:

“QQué haré? Pues mi corazón desfallece, mujeres, al ver el brillo de los ojos de mis hijos... ¿Por qué tengo que, por hacer sufrir a su padre con la desgracia de ellos, procurarme yo misma un mal que es el doble?" (vv. 1042-1047).

No hay duda de que en estos ejemplos la acción está en el centro de la trama, determinándola en su estructuración. 
Con todo, ¿se trata de una acción en trance de cumplirse, o, antes bien, de una acción cumplida? ${ }^{13}$

Si es acción por cumplirse, la tragedia se ajusta a lo que proponemos llamar la instancia del dilema. A semejanza de los magistrados que conducen los destinos legales de la ciudad, y cuyas tareas administrativas se resumen en una sola actividad general, la que consiste en zanjar con un "sí" o un "no" los hechos contenciosos que oponen a los ciudadanos entre sí, los héroes de la tragedia se ven enfrentados a situaciones disyuntivas, contradictorias, opuestas, que reclaman la toma de una decisión. No están, pues, exentos de dudar cuando se ven abocados a elegir entre dos expectativas encontradas. La duda, la vacilación o el dilema, sombrea, en el seno de la tragedia, la doble actuación lírica y recitada del coro y de la figura heroica. Pero esa vacilación recae con fuerza en el héroe.

Con otras palabras: si el agón precede, acompaña o sucede a una acción determinada, la efectuación de ésta no se produce sin que el héroe vea abrirse ante sí un horizonte entreverado de dos o más opciones. Cualquiera de ellas, de partida, se le presenta como algo viable a la vez que equívoco. Viable, puesto que cuenta con el poder y los medios a su alcance para ejecutarla; y equívoca, ya que, de elegir alguna, sabe que puede fallar, sin alcanzar a sospechar por completo las consecuencias que su elección habrá de desatar. Las dos alternativas que dan forma al dilema muerden el corazón, remueven el pecho o sacuden el alma (todas metáforas trágicas) de aquel que está a un paso de actuar. Tanto lo perturba esa indecisión psicológica que, en lugar de guardarla para sí, en su propia interioridad, la exterioriza públicamente ante los oídos de alguien más, llámese actor cuyo papel hace parte de la cuerda del héroe, llámese personaje neutro, llámese oponente. El destilado de la duda que lo consume se vierte en palabras, a cuál más apasionada y temerosa, en un intento por encontrar cierta serenidad en el acto de plasmación verbal. Vemos al personaje actuante manifestar por medio del lenguaje, con expresiones de

13 Si no fuera porque damos la impresión de que violamos resueltamente el principio de no contradicción, sostendríamos que se trata de acciones cumplidas que dan origen a dilemas actanciales, y de dilemas actanciales que desembocan en acciones cumplidas. En Agamenón, el dilema se resuelve en la acción sacrificial de su hija, y ésta, si tomamos la saga épica en conjunto, empuja la acción bélica hasta la toma, destrucción y saqueo de Troya (incluso, hasta la profanación e incendio de sus templos). Al regresar a Micenas, el soberano, pese a las dudas que lo asaltan, cede a los ruegos de su esposa y, en un acto de vanidad enmascarada, pisa el tapete rojo y con ello se engancha a la cadena de episodios que han de conducirlo a su dolosa muerte. En Áyax, el héroe pasa de la acción cumplida (el descuartizamiento del ganado cuyos individuos él confunde, en su enloquecida mente, con los jefes argivos) a un estado psicológico de indecisión (dar la cara y aceptar que "no puede ser que lo hecho venga después a suceder de otro modo" -v. 377-378-, o abandonarse por entero a su mísera condición, reconociendo que ya no se sabe "deudor a los dioses de servicio ninguno" -vv. 489-590-); indecisión que, tras apasionados y ambiguos razonamientos, lo arrastran al suicidio. En Medea, la heroína avanza desde acciones cumplidas (dar muerte a su hermano y hacer que Pelias muera arteramente a manos de sus hijas), a un terrible estado de vacilación (asesinar a Glauce y a su padre y matar a sus propios hijos); vacilación que, como ya sabemos, termina en un acto de regicidio y filicidio.

Araucaria. Revista Iberoamericana de Filosofía, Política y Humanidades, año 17, n 33. Primer semestre de 2015. Pp. 31-58. ISSN 1575-6823 e-ISSN 2340-2199 doi: 10.12795/araucaria.2015.i33.02 
ahogo, dolor, miseria, llanto, impotencia, animadversión e incertidumbre, la encrucijada vital en que se encuentra y de cuya resolución depende su propio destino y el de otros.

Si la instancia del dilema sobrelleva una larga historia entre los griegos, ¿en qué punto radica su valor como para que sea incorporada a la tragedia? No, sin duda, en el hecho formal de que obedece a una ley interna de composición dramática; sí, en cambio, en el hecho sustantivo de que trascribe imitativa y críticamente una nueva significación social.

Dicho más claramente, el dilema aparece en la tragedia porque, en primer lugar, el cuerpo de ciudadanos que asiste al teatro se auto-comprende como un conjunto de hombres, y no de héroes, en el marco de una concepción antropológica que procura discernir, a despecho de una unidad difícil de alcanzar, sus propias contradicciones, explícitamente señaladas por el célebre primer estásimo que el coro entona en una obra como Antígona. De todas las maravillas que la "soberana e incansable Tierra" crea para ser objeto de contemplación, una, sólo una, excede, aventaja, sobrepasa a las demás: el Hombre. Maravilla de ver, el hombre, en su discurrir evolutivo, aprendió a cultivar la tierra, a pescar, a cazar con ingenio, y gracias a la adquisición del lenguaje y "el pensamiento veloz como el viento" supo cómo forjar "costumbres de convivencia civil" (v. 355). Sin embargo, esa maravilla de ver que es el hombre, no sólo nunca podrá escapar del Hades, por más recursos que invente, sino que jamás podrá enfrentar el futuro con certidumbre. Es esta imagen del hombre, y no la de la antigua figura heroica, asistida por las divinidades en todos los trances laberínticos por los que atraviesa su existencia, la que, al estar tramada íntegramente por una dualidad incompatible (necesidad contra azar, agudeza contra ingenuidad, pensamiento contra emoción, lenguaje contra silencio, orden contra caos, legalidad contra ilegalidad, bondad contra maldad, etc.), la ciudad discute bajo la forma dramática del dilema.

$\mathrm{Y}$ en segundo lugar, porque el dilema, al ser vertido en palabras, al ser expresado lingüísticamente (mediante comentarios, oraciones, imprecaciones, himnos, anuncios, etc.), ingresa en un dominio aún más problemático: el de la dilogía, es decir, el dominio que comporta el uso de una expresión con dos significados diferentes dentro de una misma frase u oración. De dilogías, por no decir anfibologías (cláusulas de dos o más sentidos), observa Segal, están plagados los enunciados que conforman el texto trágico. Términos como "phílos (amigo), philía (amistad), kérdos (provecho), thymé (honor), sébas (temor), tólma (audacia), orgé (ira), deinós (terrible)" (Citado por Vernant y VidalNaquet, 1998: 38) y muchos más, acaso menos desconocidos y más familiares, salpican las intervenciones cantadas del coro y los diálogos entre los actores. No por ser coloquiales, esas expresiones dejan de cargarse con significaciones y referencias cruzadas que son entresacadas de ámbitos diferentes. La escena se 
llena de vocablos de raigambre antigua cuyos sentidos, en boca del coro o los personajes, pueden estrellarse entre sí. Creyendo que usa una lengua común, alguien, al hablar, se topa con otro que parece emplear los signos de una lengua extranjera. Y el extranjero, que por definición articula una lengua bárbara, no deja de sorprenderse al ser comprendido por quien no es nativo de su localidad. Para los griegos, el menos llamado a razonar, niño, esclavo o mujer, profiere sin embargo enunciados sensatos, cuyas palabras consultan el sentir de la comunidad; en cambio, aquellos naturalmente convocados para hacer uso del lenguaje, hombres y gobernantes, dan muestras de no saber disputar tomando en consideración la genuina polisemia de los signos que ventilan en público ${ }^{14}$. Incluso en los pasajes en los que los personajes hablan según una estructura que hace avanzar el diálogo en líneas individualizadas, verso a verso, es posible oír latir la lógica de los dissoi logoi, alocuciones dobles cuyas palabras toman el sentido que más conviene a la causa del orador, del sofista, del actor, y que, surtidos de indeterminación, van y vienen, a semejanza de una marea discursiva, en espera de que lo dicho se realice efectivamente en la acción y se sustraiga a la instancia del dilema en la que se sustenta.

Ahora bien, si es acción cumplida, y no acción por realizarse, la tragedia oscila entre dos condicionamientos. Debemos el primero a Aristóteles. Acción cumplida no significa únicamente resolución del dilema actancial, dentro de una atmósfera cargada de tensión (producto de la situación conflictiva que el héroe contribuye a crear con su forma de comportarse) y moteada de fatalidad (dada la naturaleza desmesurada de la acción misma). Tampoco significa sólo conducta humana ejecutada en un tiempo específico (el pretérito perfecto simple del modo indicativo) y en un espacio determinado o indeterminado (aquí, allá,

${ }^{14}$ Por ejemplo, la noción de kratos, asociada a kýrios (señor) “en boca del rey Pelasgo, designa una autoridad legítima, el dominio que ejerce con pleno derecho el tutor sobre aquel que jurídicamente depende de su poder; en boca de las Danaides la misma palabra, atraída al campo semántico de bía (violencia), designa la fuerza brutal, la coacción de la violencia en su aspecto más opuesto a la justicia y al derecho" (Vernant y Vidal-Naquet, 2002: 34). La misma palabra, kratos, se desdobla en dos líneas de significación y, según sea su uso por parte de uno u otro personaje, fluidifica el diálogo o paraliza la comunicación. Mientras la tirada coral o dialógica no se despliegue en toda su extensión, es difícil determinar si los postulados de sentido de una expresión se mantienen o se varían en cada ocasión. Igualmente, la polis de la que hace mención Medea, en los versos 1021 y ss, y con la cual da inicio al parlamento que antecede la entrega de los dones con los cuales matará a Glauce y al rey, no significa primariamente una comunidad de ciudadanos que en vida consagran su existencia al bienestar colectivo, sino que significa secundariamente la morada donde sus hijos "vivirán para siempre, privados de su madre", una vez proceda a asesinarlos. Y el hombre (áner) del que dice estar locamente enamorada Fedra, hasta el punto de que la sola invocación de su nombre por parte de la nodriza la debilita (v. 313), en Hipólito, no responde al modelo cultural ateniense de lo masculino: como cazador que recorre los prados y montes consagrados a Artemis, y por ende que se aleja de los espacios públicos donde transcurre la vida de un auténtico ciudadano, apenas es un adolescente casto que se rehúsa a tener contacto con las mujeres. Al negarse a aceptar el código de Afrodita, expuesto en el prólogo, Hipólito posterga desmedidamente su paso a la vida adulta, que está representada tanto por la necesidad de contraer matrimonio como por la participación en la vida política, y es esa postergación la que lo conducirá a la ruina.

Araucaria. Revista Iberoamericana de Filosofía, Política y Humanidades, año 17, n 33. Primer semestre de 2015. Pp. 31-58. ISSN 1575-6823 e-ISSN 2340-2199 doi: 10.12795/araucaria.2015.i33.02 
más allá, en algún lugar). Acción cumplida significa, además, acción imitada de acuerdo con el fin que la tragedia busca (télos) y según un programa dramático que se compone de estados y movimiento.

En cuanto al programa dramático, Aristóteles, fiel a su inclinación de preferir siempre, respecto de los asuntos tratados, el término medio, plantea dos situaciones humanas extremas, pero posibles, que, de ser convertidas en objeto de representación teatral, resultarían contrarias a la esencia del movimiento trágico (Poética,1453a 1 y ss): primera, imitar sobre las tablas a hombres nobles, virtuosos, esforzados cuya vida presente pasa de un estado de felicidad, de dicha, de fortuna, a otro de infelicidad, de desdicha, de infortunio. Tal posibilidad, estima el filósofo, lejos queda de suscitar los sentimientos mencionados para procurar el placer que es propio de la tragedia, y, antes bien, despierta, entre quienes la ven u oyen (¿y leen?), uno de "repugnancia". Aunque una obra como Hipólito respondería a este esquema, queda por averiguarse si, a los ojos de un ciudadano ateniense, el protagonista encarna las virtudes propias de un hombre político o si, al contrario, su destino trágico es fruto de una obstinación pre-política. Segunda: imitar sobre las tablas a hombres bajos, viciosos y malvados cuya vida presente transita de un estado de infortunio a otro de fortuna. Tal opción, de modo similar, "no inspira simpatía, ni compasión ni temor”. Quizás este segundo movimiento resulte más apto para hacer reír que para hacer llorar. De hecho, consagra el esquema que a menudo sigue la comedia de Aristófanes. Si no fuera por su final (en el que la tesis sobre la vieja y nueva educación queda remarcada), diríamos que, en Las nubes, el anciano y paleto Estrepsíades obtiene un estado de mejoramiento, luego de los infortunios económicos que le acarrean las apetencias de su esposa y las inclinaciones hípicas de hijo. Resta, así, una alternativa intermedia, asimismo posible, que es la que Aristóteles reputa como la mejor y más adecuada para expresar dramáticamente el acontecimiento que define la tragedia: imitar sobre las tablas el caso de un personaje "que ni sobresale por su virtud y justicia ni cae en la desdicha por su bajeza y maldad, sino por algún yerro, siendo de los que gozaban de gran prestigio y felicidad, como Edipo y Tiestes y los varones ilustres de tales estirpes" (ibid., 1453a5-10).

Las tres posibilidades incluyen, junto a momentos de estado y movimiento, hombres responsables de ellos. Ya en su definición, Aristóteles señala que la tragedia es acción y vida. No es el tipo de acción que la naturaleza origina siguiendo las leyes que le son inherentes (llover, dejar de llover, tronar, incendiar), sino el tipo de acción que, concebida como conducta o comportamiento ficticio, compromete la presencia activa o pasiva de un ser humano. Y es menos la vida que concierne a los dominios naturales no humanizados, que la que incumbe al cosmos humanizado. Acción cumplida, y generadora de temor y compasión, y vida sometida, como la de cualquier ser humano, a los embates y reveses de 
la fortuna. A este respecto, Sánchez Giraldo anota que el estado inicial y final de la situación trágica, antes que corresponder a una entidad abstracta, atañe exclusivamente a "la persona que es sujeto del drama y no como referidos a toda la situación" (2008: 30).

En tanto que resolución del dilema actancial, la acción cumplida es un tipo de conducta que, salvo en algunas excepciones -Las Euménides, Edipo en Colono, Alcestis-, conduce a la muerte propia o a la de alguien más. Lo que interesa, en el contexto de un pensamiento jurídico que para entonces apenas está en trance de elaboración, no es calificar el acto como hecho afortunado o infortunado (cosa de suyo evidente, en tratándose de enemigos o amigos), sino averiguar qué motiva al héroe a realizarlo y qué sentido se desprende después de haberlo cometido. ¿Es un poder demoníaco el que toma posesión del cuerpo y la mente del héroe y lo arrastra ineludiblemente a la comisión del crimen? ¿Es el hombre el que, a sabiendas, como en Medea, o sin saberlo, como en Edipo rey, opta por violar la ley que impide hacer justicia privada? La primera pregunta entraña una concepción religiosa tradicional. Para ésta la acción ejecutada es producto de una ceguera humana (hamartía) que halla su fuente en los ignotos designios de una divinidad. La segunda pregunta implica una nueva concepción psicológica y jurídica que declara que el hombre es el responsable de sus actos y que éstos, al ser realizados, generan unas consecuencias punibles cuyo significado revelan al agente su propia condición. Sin embargo, ninguna de las dos concepciones acusa un carácter absoluto. Cada una, a su manera, tiene su cuota de participación en el modo como la ciudad intenta sopesar la acción. Las dos forcejean entre sí, oponiéndose, pero sin llegar a destruirse. Como afirma Vernant, "la ambigüedad del error o del crimen se compone de la tensión de la posición moral trágica del héroe entre la antigua concepción religiosa de la corrupción criminal, de la hamartía, como una enfermedad espiritual o mental, una locura (até) causada por los dioses que necesariamente engendra el crimen, y la nueva concepción según la cual el culpable, hamartón (y adikón) se define como alguien que, sin ser obligado a ello, ha elegido deliberadamente transgredir la ley" (1972: 308).

Al lado de la diké ancestral, presente no sólo en Homero y Hesíodo, sino también en poetas líricos como Tirteo ("Zeus de ustedes los ojos aún no apartó" -fr. 7 [8D]-), Solón ("Los inmortales les dan su ganancia a los hombres, y de ellos procede también el desastre que, cuando Zeus lo envía en castigo, sufre cada uno a su tiempo" -fr. 2 [2D]-), Arquíloco ("Profeta es Zeus supremo entre los dioses: es él quien prescribe el final"-fr. 77 [84D]-), Semónides ("Muchacho, es Zeus tonante quien prescribe de todo el desenlace, y quien lo pone por donde él quiere"-fr. 1 [1D]-) (Ferraté, 2000), quienes la cantan como imagen jurídica de la trascendencia, $y$, por ello mismo, soberana e inaccesible pero siempre actuante, la ciudad comienza a concebir un concepto de justicia que toma en 
cuenta el grado de implicación del hombre en la acción ejecutada, su eventual intencionalidad, así como su posible responsabilidad. Y no sólo eso: supone que las consecuencias derivadas de la acción dotan de sentido, en una unidad inseparable, "la ceguera, el acto criminal y el castigo". ¿Cuál es ese sentido? "Para el griego, si haces algo, lo que procede de tu acto es lo que tú has hecho. Sabes que eres criminal porque eres castigado. Esto no quiere decir que no eras criminal, que no eras responsable; pero comprendes que eres un criminal porque has sido castigado. Esto quiere decir que el hombre trágico carga con el peso de la responsabilidad de sus actos, y se siente, en un sentido, como la causa; pero al mismo tiempo no puede considerarlos fuera de un contexto de poder religioso" (1972: 309). Sea consecuencia de un error, sea fruto de un carácter que, por su desmesura, puede equivocarse, la acción trágica, como acción cumplida, oscila por consiguiente entre dos concepciones contrapuestas, la religiosa y la jurídica. Ambas pesan lo suyo, pero ninguna de las dos termina por aplastar a la otra. Si la primera se hubiera superpuesto a la segunda, o si ésta hubiera anulado a aquélla, Atenas no habría conocido la figura del hombre trágico. El equilibrio que ambas consiguen, pese a sus mutuas tensiones, es lo que garantiza la existencia del hombre trágico. En él, tanto si realiza una acción como si está apunto de ejecutarla, pervive la instancia del dilema.

\section{Conclusión}

La tragedia, ¿qué pone en escena? ¿qué lleva al tablado? No el hombre a secas, llámese rey, ciudadano o esclavo. Más cercana a una concepción moderna, esta idea les resultaría extraña a los griegos. Y no porque en sus reflexiones sobre la dimensión antropológica del ser vivo no tuvieran en cuenta la especificidad de aquel a quien consideraban un compuesto de carne y alma, sino porque, a diferencia de otros momentos históricos, supeditaban la valoración del hombre a una entidad suprema, cronológicamente posterior al mismo pero ontológicamente anterior: la pólis. Para los griegos, la pólis es condición de posibilidad del hombre y no al revés. El teatro, en consecuencia, es el lugar donde se escenifica -bajo la forma de una mímesis- la vida cívica. Todo lo que regula esta vida-religión, economía, política, cultura, etc.- es elevado a un plano de relevancia en el que, por medio del canto y el recitado, el cuerpo cívico se auto-contempla a sí mismo. La visión del nosotros reclama un distanciamiento momentáneo, aunque regular, que instale (en el ámbito de la ficción) la imagen del otro que constitutivamente somos.

Como expresión artística de una ciudad (Atenas) que deja atrás la asimetría propia de los asentamientos de soberanía para dar curso a las relaciones horizontales entre los hombres, la tragedia es la forma poética inventada por 
los atenienses con el fin de tender un puente entre el pasado aristocrático y el presente democrático. Sin ser explícitamente una modalidad estética al servicio de fines políticos, no deja de aunar, al lado de sus propios rasgos formales, un contenido que toca vivamente el interés general de todos los que, en calidad de ciudadanos, componen la mancomunidad de la ciudad. Enmarcado por una festividad que honra la epifanía de un dios poco noble o eminente, dicho interés se despierta cuando los tragediógrafos, en su condición de servidores públicos (pues el arte de su magisterio tiene sentido si y sólo si está dirigido a otros), revisitan el pasado mítico y lo actualizan, transformado en drama ficticio o en ficción dramática, al amparo de un clima artificial auspiciado por la ciudad misma. Antes que teñido de nostalgia, su anacronismo está salpicado de un espíritu crítico, derivado de la nueva racionalidad imperante en los más diversos ámbitos de la vida social ateniense. Lo que se interroga, en la figura del héroe antiguo, no es tanto la eminencia de su gesta cuanto la conveniencia de mantener el ideal de los códigos que regulan su existencia. Y se interroga tal ideal, con los recursos que provee la palabra proferida públicamente, y bajo la forma de un debate que tiene por modelo las discusiones acaecidas en el seno de los órganos de gobierno, porque la ciudad, que está representada en la orquestra del edificio teatral por el coro, se halla en plena elaboración de otros ideales, más ajustados al móvil igualitario en el que se fundamenta esa "ordenación de las magistraturas" denominada democracia. Dado que esta ordenación se afinca en la noción de comunidad (koinonía), y dado además que no puede hablarse de comunidad a menos que exista un conjunto de palabras y acciones necesarias para la "vida buena" (más que para el mero vivir), entonces nada hay más alejado de este propósito que la conservación de un ideal de vida gobernado por la noción de proeza individual y gesta gloriosa. 


\section{Referencias bibliográficas:}

Aristóteles. (1988). Política. Introducción, traducción y notas de Manuela García Valdés. Madrid: Cátedra.

Aristóteles. Poética. (1985). Traducción de Juan David García Bacca. México: Bibliotheca scriptorvm graecorvm et romanorvn mexicana.

Bauzá, H. (2007). El mito del héroe. Morfología y semántica de la figura heroica. Buenos Aires: Fondo de Cultura Económica.

Brioso Sánchez (2005). "Las mujeres, ¿espectadoras del teatro clásico griego?”. En: Habis. Sevilla: Universidad de Sevilla, ISSN 0210-7694, N 36, pp. 77-98.

Bowra, C. M. (2003). La Atenas de Pericles. Madrid: Alianza Editorial.

Castoriadis, C. (2006). Lo que hace a Grecia. 1. De Homero a Heráclito. Seminarios 1982-1983. La creación humana II. Buenos Aires: Fondo de Cultura Económica.

De Romilly, J. (1997). ¿Por qué Grecia? Madrid: Debate.

Diccionario Griego-Español (1999). Publicado bajo la dirección de Florencio I. Sebastián Yarza. Barcelona: Sopena.

Echavarría Yepes, S. (2012). "Del mito al mythos. Un ensayo de hermenéutica homérica". En: El caduceo de Hermes. Estudios de hermenéutica teórica y aplicada. Editores: Juan Manuel Cuartas Restrepo y Mauricio Vélez Upegui. Bogotá: San Pablo.

Esquilo. (2000). Tragedias. Introducción general de Francisco Rodríguez Adrados y Traducción y notas de Bernardo Perea Morales. Madrid: Gredos.

Eurípides. (2000). Tragedias. I. Alcestis-Medea-Los Heráclidas-HipólitoAndrómaca-Hécuba. Introducción general de Carlos García Gual. Introducciones, traducción y notas de Alberto Medina González y Juan Antonio López Férez. Madrid: Gredos.

Eurípides (2000). Tragedias II. Heracles-Ion-Las troyanas-Electra-Ifigenia entre los Tauros. Introducciones, traducción y notas de José Luis Calvo Martínez. Madrid. Gredos.

Eurípides. (2000). Tragedias. III. Fenicias-Orestes-Ifigenia en ÁulideBacantes. Introducciones, traducción y notas de Carlos García Gual. Madrid: Gredos.

Ezquerra Gómez, J. (2009). "Pólis y Caos. El espacio de lo político". En: Res publica, V. 21, (ene-jun); Madrid, pp. 21-37.

Ferraté, J. (2000). Líricos griegos arcaicos. Barcelona: El acantilado.

Finley, M. (2014). El mundo de Odiseo. México: Fondo de Cultura Económica. García Bacca, J.D. (2000). "Introducción a la Poética”. En: Aristóteles. Poética. 
México: Bibliotheca scriptorvm graecorvm et romanorvn mexicana.

García Gual, C. (2006). Historia, novela y tragedia. Madrid: Alianza Editorial. Gil Fernández, L. (2009). Sobre la democracia ateniense. Madrid: Editorial Dykinson.

Ghul, E. y Koner, W. (2002). Los griegos. Su vida, sus costumbres. España: Edimat Libros.

Guthrie, K. C. W. (2005). Los filósofos griegos. México: Fondo de Cultura Económica.

Guzmán Guerra, A. (2005). Introducción al teatro griego. Madrid: Alianza Editorial.

Hesíodo. (2000). Obras y fragmentos. Teogonía-Trabajos y Días-EscudoFragmentos-Certamen. Introducción general de Aurelio Pérez Jiménez. Traducción y notas de Aurelio Pérez Jiménez y Alfonso Martínez Díez. Madrid: Gredos.

Iriarte, A. (1996). Democracia y tragedia: la era de Pericles. Madrid: Akal.

Liddell, H. G. y Scott, R. (1953) Greek-English Lexicon. Gran Bretaña: University Press, Oxford.

Lesky, A. (2001). La tragedia griega. Barcelona: El acantilado.

Nietzsche, F. (2004). El pensamiento trágico de los griegos. Escritos póstumos

1870-1871. Edición de Vicente Serrano. Madrid: Biblioteca Nueva.

Ortega y Gasset, J. (1993). La rebelión de las masas. Madrid: Altaya.

Platón. (1996). República. Introducción, traducción y notas por Conrado Eggers Lan. Madrid: Gredos.

Platón. (2006). Eutifrón. Introducción de Emilio Lledó. Madrid: Gredos.

Posada González, M. C. (1986). Ares y Afrodita. De la tragedia a la ópera. Medellín: Impresión U.P.B.

Ricoeur, P. (1992). "Una reaprehensión de la Poética de Aristóteles". En:

Nuestros griegos y sus modernos. Estrategias contemporáneas de apropiación de la Antigüedad. Textos reunidos por Bárbara Cassin. Buenos Aires: Manantial.

Rodríguez Adrados, F. (1983). Fiesta, comedia y tragedia. Madrid: Alianza Editorial.

Rosenmeyer, T. G. (1983). "Teatro". En: El legado de Grecia. Una nueva valoración. M. I. Finley, ed. Barcelona: Crítica.

Sánchez Giraldo, S. (2008). De la tragedia griega al drama moderno. Medellín: Editorial Universidad de Antioquia.

Sinclair, R. K. (1999). Democracia y participación en Atenas. Madrid. Alianza Editorial.

Sófocles (2001). Tragedias. Introducciones de Jorge Bergua Cavero y Traducción y notas de Assela Alamillo. Madrid. Gredos. 
Teofrasto. (1985). Los caracteres. Madrid: Centro de Estudios Constitucionales. Tucídides. (1999). Historia de la guerra del Peloponeso. Traducción y notas de Juan J. Torres Esbarranch. Madrid: Planeta DeAgostini.

Vegetti, M. (1995). "El hombre y los dioses". En: El hombre griego. Edición de Jean-Pierre Vernant. Madrid: Alianza Editorial.

Vélez Upegui, M. (2013). “Tragedia y reaprehensión mítica” En: Co-herencia. Revista de Humanidades. Medellín: Universidad Eafit, ISSN 1794-5887, Vol. 10, N 19 (Jul-dic/13): 73-112.

Vernant, J-P. (1972). "La tragedia griega: problemas de interpretación". En: Macksey, R. y Donato, E. Los lenguajes críticos y las ciencias del hombre. Controversia estructuralista. Barcelona: Barral Editores.

Vernant, J-P. (1992). Los orígenes del pensamiento griego. Barcelona: Paidós Studio.

Vernant, J-P. (2002). Entre mito y política I. México: Fondo de Cultura Económica.

Vernant, J-P. (2008). Atravesar fronteras. Entre mito y política II. México: Fondo de Cultura Económica.

Zimmermann, B. (2012). Europa y la tragedia griega. De la representación ritual al teatro actual. Madrid: Siglo XXI. 